\title{
The use of D-optimal design in optimization of wool dyeing with Juglansregia bark
}

\author{
DOI: 10.35530/IT.069.02.1509
}

\author{
AMINODDIN HAJI \\ S. SADRODDIN QAVAMNIA
}

MAJID NASIRIBOROUMAND

\section{REZUMAT - ABSTRACT}

\section{Utilizarea modelului D-optimal în optimizarea vopsirii lânii cu coaja de Juglansregia}

În acest studiu, fibrele de lână au fost vopsite folosind coaja de Juglansregia ca o nouă sursă de colorant natural. Alaunul a fost utilizat ca mordant. Metodologia de suprafață a răspunsului şi modelul D-optimal au fost utilizate pentru studierea şi optimizarea procedeului de vopsire, cu scopul de a obține intensitatea maximă a culorii după vopsirea cu extractul apos de coajă de Juglansregia. Rezultatele au arătat că intensitatea culorii fibrelor vopsite a crescut prin creşterea timpului de vopsire şi a temperaturii şi a scăzut prin creşterea valorii pH-ului băii de vopsire. A existat o valoare optimă de aproximativ $6 \%$ owf pentru concentrația de mordant. Condiția optimă pentru obținerea intensității maxime a culorii a fost următoarea: $\mathrm{pH}$-ul băii de vopsire: 6 , concentrația de alaun: $6,24 \%$ owf, temperatura de vopsire: $90{ }^{\circ} \mathrm{C}$ şi timpul de vopsire: $90 \mathrm{~min}$.

Cuvinte-cheie: mordant, colorant natural, lână, optimizare, RSM

\section{The use of D-optimal design in optimization of wool dyeing with Juglansregia bark}

In this study, wool fibers were dyed using the Juglansregiabark as a new source of natural dye. Alum was used as mordant. Response surface methodology and D-optimal design were employed to study and optimize the dyeing procedure with the aim of obtaining the maximum color value after dyeing with aqueous extract of Juglansregiabark. The results showed that the color value of the dyed fibers was increased by increasing the dyeing time and temperature and decreased by increasing the dyebath $\mathrm{pH}$ value. There was an optimum value of around $6 \%$ owf for mordant concentration. The optimal condition for obtaining the highest color value was as follows: dyebath $\mathrm{pH}$ : 6 , alum concentration: $6.24 \%$ owf, dyeing temperature: $90^{\circ} \mathrm{C}$, and dyeing time: $90 \mathrm{~min}$.

Keywords: mordant, natural dye, wool, optimization, RSM

\section{INTRODUCTION}

Natural dyes are known as sustainable and environmentally friendly materials for dyeing and functional finishing of textiles [1]. They can be obtained from vegetable, animal or mineral origin [2]. Several studies have been reported on application of different natural dyes on textile fibers. Barberry tree root, cumin seeds, grape leaves and pomace, red cabbage, milkweed leave, Achilleapachycephala flowers, almond shell, pomegranate rinds and wastewater of olive oil production are examples of new sources of natural dyes which have been studied in recent years [3-17]. Despite several advantages associated with the use of natural dyes in dyeing textile goods, there is a great need for optimization of natural dyeing processes to fulfill the equipments of today's industry. Metal mordants are commonly used in order to increase the uptake and fastness of natural dyes on textile fibers and obtain different shades using a single dye [18]. However, most of metal mordants cause environmental problems as well as health concerns for the consumers [19]. Natural dyeing plants usually posses low color yield and require prolonged time to dye textiles satisfactorily. Several pretreatments like cationization, plasma treatment, enzyme treatment, gamma treatment, and microwave treatment are examples of techniques which have been studied to overcome this drawback [7, 10, 20-24]. To minimize the consumption of energy, dye, mordant, and auxiliaries besides decreasing the required time, while gaining the highest dyebath exhaustion, optimization of the dyeing process is really important [25].

In the traditional method for optimization of processes, experiments are first performed and the measured data is analyzed afterwards. This approach examines one variable at a time and is time and work demanding and the effect of interactions between different factors is not taken into account [26]. In contrast to this, in statistical methods, the experimental design is planned and sets of well selected experiments are performed to get the most informative combination out of the assumed factors with the minimum number of experiments. Response surface methodology (RSM) offers design of experiment (DOE) tools that lead to refined optimization approaches and process performance at minimal cost [27]. D-optimal designs create the optimal set of experiments on the basisof a computer-aided exchange procedure. This method selects the best combination of experimental trials within the limitations provided and provides maximum accuracy in estimating regression coefficients. The optimality criterion results in 
minimizing the generalized variance of the parameter estimates for a pre-specified model [28-29].

Juglansregia is a tree native to central Asia and can be found in several countries all over the world. Many parts of this tree including green walnuts, shells, seed, bark, and leaves are used in the pharmaceutical and cosmetic industry. The bark of this tree is used as a toothbrush and a dye for coloring the lips for makeup purpose is some parts of south of Iran. It contains several phenolic compounds namely, $\beta$-sitosterol, juglone, folic acid, gallic acid, regiolone, and quercetin-3- $\alpha$-L-arabinoside [30-31].

In this study, the bark of Juglansregiatree was chosen as a new source of natural dye for coloration of wool fibers. Four independent factors including mordant concentration, dyebath $\mathrm{pH}$, and temperature besides the dyeing time were selected as the most influencing factors according to preliminary experiments. To find out the optimum conditions for dyeing procedure, D-optimal design was used and the effect of dyeing process factors on the color value of the dyed samples was determined.

\section{EXPERIMENTAL WORK}

\section{Materials and methods}

Pure wool fabric (plain weave, $250 \mathrm{~g} / \mathrm{m}^{2}$ ) was purchased from Iran Merinos Textile Company, Iran, and used for the experiments after scouring and drying (1\% non-ionic detergent (Triton X-100, SigmaAldrich, USA), $50^{\circ} \mathrm{C}$, for $30 \mathrm{~min}$ ). All other chemicals used in this study were analytical grade reagents obtained from Merck, Germany.

Juglansregia bark was washed with tap water, dried and then powdered. $100 \mathrm{~g}$ of powder was used for preparation of 1 liter of the original dye solution. Distilled water was used for this purpose and boiling was continued for $2 \mathrm{~h}$ and then the solution was filtered. The concentration of the prepared solution is $10 \% \mathrm{~W} / \mathrm{V}$.

Experimental Design: The formulation of experiments and statistical analysis of responses were performed using Design Expert software (version 7.0). In this study, the most influencing operating factors of the natural dyeing process were optimized using response surface methodology (RSM) and D-optimal design. The practically feasible ranges for each factor were determined by preliminary studies before designing the experiments. Table 1 presents the corresponding codes besides lower and higher values for each variable.

Table 1

\begin{tabular}{|c|l|c|c|c|}
\hline \multicolumn{5}{|c|}{ EXPERIMENTAL RANGES OF FACTORS } \\
\hline Factor & \multicolumn{1}{|c|}{ Name } & Unit & Low level & High level \\
\hline A & Dyeing pH & - & 4 & 8 \\
\hline B & $\begin{array}{l}\text { Mordant } \\
\text { concentration }\end{array}$ & $\%$ owf & 0 & 10 \\
\hline C & $\begin{array}{l}\text { Dyeing } \\
\text { temperature }\end{array}$ & ${ }^{\circ} \mathrm{C}$ & 50 & 90 \\
\hline D & Dyeing time & min & 30 & 90 \\
\hline
\end{tabular}

A total number of 25 experiments were proposed by the software. P-value with 95\% confidence level was considered for the selection or rejection of the model terms. To analyze the results, ANOVA was employed. Response surfaces were drawn to determine the individual and interactive effects of the process variables on the color value of dyed samples.

Mordanting: The mordanting bath was prepared using the required amount of alum (aluminum potassium sulfate) according to the experimental design and acetic acid was used for adjustment of $\mathrm{pH}$ at 5 . The liquor to goods ratio (L:G) was 50:1 and the mordanting was done at boil for $1 \mathrm{~h}$.

Dyeing: Dyeing of the samples was performed using $50 \%$ owf of the natural dye $(\mathrm{L}: \mathrm{G}=40: 1, \mathrm{pH}=4-8)$. The dyeing was started at $40^{\circ} \mathrm{C}$ and the temperature was raised to the final temperature at the rate of $2^{\circ} \mathrm{C}$ per minute. Then the samples remained in that condition for the predefined time according to the experimental design, and then rinsed and air dried.

Color value measurements: the reflectance of dyed samples were measured on a Color-eye 7000A spectrophotometer using illuminant D65 and $10^{\circ}$ standard observer. Color strength (K/S) of each dyed sample was calculated using kubelka-munk equation for each wavelength ranging between $360-740 \mathrm{~nm}$ :

$$
K / S=(1-R)^{2} / 2 R
$$

Where $R$ is the observed reflectance, $K$ - the absorption coefficient and $S$ - the light scattering coefficient. For better comparison of the samples in the full range of the visible spectrum, the sum of color strengths measured at all wavelengths (color value sum or $C V_{\text {sum }}$ ) was calculated and considered for further analysis.

$$
C V_{\text {sum }}=\Sigma_{360}^{740}(K / S)
$$

\section{RESULTS AND DISCUSSION}

\section{Model fitting and statistical analysis}

The experimental conditions and color values $\left(C V_{\text {sum }}\right)$ of the woolen fabric samples dyed with $50 \%$ owf of natural dye are shown in table 2. The data obtained from the colorimetric analysis of the dyed samples were fitted to various models. ANOVA results of fitting different models to the obtained data are shown in table 3 . The quadratic model was the most suitable model for describing this process. The analysis of variance was used for measuring up the significance of the effect of the dyeing process variables and their interactions on the $C V_{\text {sum }}$ as the response. A $P$-value less than 0.05 was considered as a sign which confirms that the model and the terms are statistically significant. In case that many insignificant model terms are found, model reduction which means the elimination of the insignificant factors from the model can improve the final model. In this study, model reduction was performed by the software and some insignificant interactions of the variables having $P$-values higher than 0.05 were eliminated. 


\begin{tabular}{|c|c|c|c|c|c|}
\hline \multicolumn{6}{|c|}{ EXPERIMENTAL DESIGN OF DYEING PROCEDURES AND RESPONSES } \\
\hline & Factor 1 & Factor 2 & Factor 3 & Factor 4 & Response \\
\hline Run & A: $\mathrm{pH}$ & $\begin{array}{c}\text { B: Mordant } \\
\text { Concentration (\% owf) }\end{array}$ & $\begin{array}{c}\text { C: Temperature } \\
\left({ }^{\circ} \mathrm{C}\right)\end{array}$ & $\begin{array}{l}\text { D: Dyeing time } \\
\text { (min) }\end{array}$ & $\mathrm{CV}_{\text {sum }}$ \\
\hline 1 & 4 & 10 & 50 & 30 & 71.4 \\
\hline 2 & 8 & 0 & 50 & 90 & 72.2 \\
\hline 3 & 8 & 0 & 50 & 90 & 61.5 \\
\hline 4 & 4 & 0 & 50 & 30 & 141.2 \\
\hline 5 & 6 & 5 & 90 & 60 & 215.5 \\
\hline 6 & 6 & 5 & 50 & 60 & 146.4 \\
\hline 7 & 8 & 10 & 50 & 90 & 127.5 \\
\hline 8 & 4 & 5 & 50 & 90 & 220.4 \\
\hline 9 & 6 & 10 & 70 & 60 & 85.2 \\
\hline 10 & 4 & 5 & 90 & 30 & 192.7 \\
\hline 11 & 4 & 0 & 90 & 90 & 62.2 \\
\hline 12 & 4 & 10 & 90 & 90 & 172.4 \\
\hline 13 & 88 & 10 & 50 & 90 & 95.8 \\
\hline 14 & 6 & 10 & 90 & 30 & 59.6 \\
\hline 15 & 8 & 0 & 90 & 30 & 133.2 \\
\hline 16 & 8 & 0 & 70 & 30 & 66.1 \\
\hline 17 & 8 & 5 & 90 & 90 & 231.6 \\
\hline 18 & 4 & 0 & 90 & 90 & 142.2 \\
\hline 19 & 6 & 2.5 & 70 & 60 & 56.8 \\
\hline 20 & 4 & 0 & 50 & 30 & 92.4 \\
\hline 21 & 8 & 10 & 90 & 30 & 100.2 \\
\hline 22 & 8 & 5 & 50 & 30 & 62.9 \\
\hline 23 & 4 & 5 & 70 & 60 & 179.7 \\
\hline 24 & 8 & 0 & 90 & 60 & 99.4 \\
\hline 25 & 8 & 5 & 70 & 60 & 123.8 \\
\hline
\end{tabular}

\begin{tabular}{|c|c|c|c|c|}
\hline \multicolumn{5}{|c|}{$\begin{array}{c}\text { ANOVA RESULTS OF THE FITTING THE } \\
\text { EXPERIMENTAL DATA TO VARIOUS MODELS }\end{array}$} \\
\hline $\begin{array}{c}\text { Source } \\
\text { model }\end{array}$ & F value & $\begin{array}{c}\text { P value } \\
\text { Prob > F }\end{array}$ & R-Squared & \\
\hline Linear & 2.78 & 0.1320 & 0.2685 & \\
\hline 2FI & 3.05 & 0.1163 & 0.4920 & \\
\hline$\underline{\text { Quadratic }}$ & $\underline{0.95}$ & $\underline{0.5196}$ & $\underline{0.8469}$ & $\underline{\text { Suggested }}$ \\
\hline Cubic & & & 0.9217 & aliased \\
\hline
\end{tabular}

Table 4 shows the analysis of variance (ANOVA) results of the established model for responses. The model $F$-value of 7.83 implies on the significance of the model. When the calculated Value for Prob $>F$ related to a certain variable is less than 0.05 , itmeans that the corresponding model term is significant at a confidence level of $95 \%$. In this case $A, C, D, B D, B^{2}$ and $C^{2}$ are significant model terms. A high $R^{2}$ coefficient confirmed a sensible concurrence between the proposed model and the experimental data.

The "Pred R-Squared" of 0.5245 was in reasonable agreement with the "Adj R-Squared" of 0.6947 . "Adeq Precision" shows the extent of divergence in predicted response regarding its associated error or

\begin{tabular}{|c|c|c|}
\hline \multicolumn{3}{|c|}{$\begin{array}{c}\text { ANOVA RESULTS OF THE ESTABLISHED MODEL } \\
\text { FOR RESPONSES }\end{array}$} \\
\hline Factor & F-Value & P-Value \\
\hline Model & 7.83 & 0.0003 \\
\hline A: Dyeing pH & 5.24 & 0.0360 \\
\hline B: Mordant concentration & 0.65 & 0.4331 \\
\hline C: Dyeing temperature & 7.90 & 0.0126 \\
\hline D: Dyeing time & 9.44 & 0.0073 \\
\hline AC & 4.25 & 0.0559 \\
\hline BD & 10.84 & 0.0046 \\
\hline B $^{2}$ & 26.32 & 0.0001 \\
\hline C $^{2}$ & 5.96 & 0.0267 \\
\hline Lack of Fit & 0.73 & 0.6947 \\
\hline
\end{tabular}

signal to noise ratio and compares the range of predicted values at design points to the average prediction error. A desirable "Adeq Precision" should be higher than 4 and indicates that the mode has been selected suitably [26]. In this case, the ratio of 9.652 impliesthat this model was well selected and can be used forhandling the design space. 
Regression analysis was performed on experimental data and the following model equation in terms of coded factors was fitted:

$$
\begin{gathered}
C V_{\text {sum }}=136.75-16.07 A+6.23 B+19.67 C+25.42 D+ \\
+17.35 A C+28.00 B D-69.09 B^{2}+39.06 C^{2}
\end{gathered}
$$

\section{The effects of parameters on color value}

To compare the effect of four factors on color value of dyed samples, perturbation plot (figure 1) was drawn. This plot shows the effect of changing each factor on $\mathrm{CV}_{\text {sum }}$ while holding three other factors constant. The reference amounts of the factors to draw the plot are shown on it. A steep slope or curvature in the resulting trace indicates sensitivity of the response to that factor. From the curvature of the plot $B$ and $C$, it can be concluded that the response is more sensitive to mordant concentration and dyeing temperature compared with other factors. The lower steep of the $\mathrm{pH}$ line shows less sensitivity of the color value to change in this factor at the range investigated in this study.

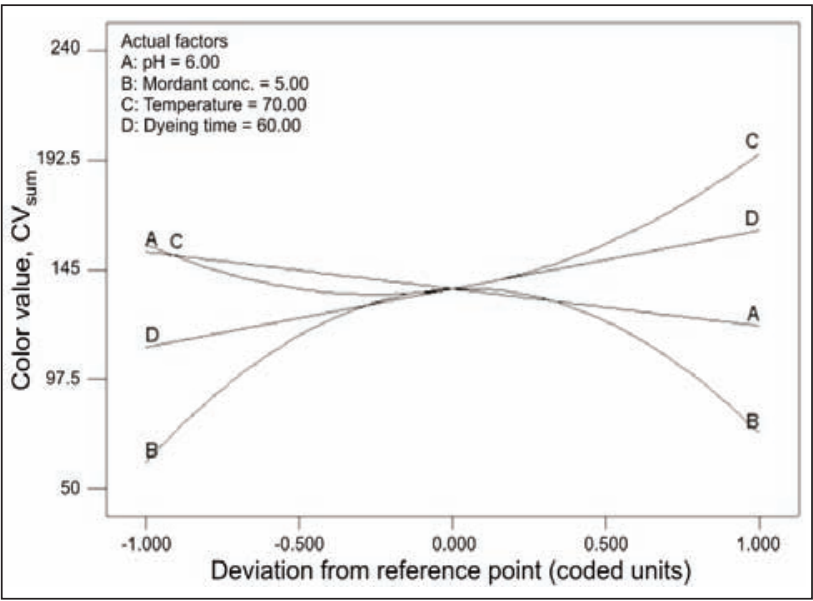

Fig. 1. Perturbation plot for $\mathrm{CV}_{\text {sum }}$

Figure 2 shows the individual and simultaneous effects of the dyeing procedure factors on color value of the dyed samples. It can be seen that the addition of alum mordant and increasing its concentration up to $6 \%$ owf has increased the color value of the dyed samples. It means that the dye uptake of the mordanted samples has been higher than the non-mordanted sample. Mordanting increases the interaction between the amine groups of wool fibers and hydrox$\mathrm{yl}$ and carbonyl groups of juglone as the main colorant present in the extract used for dyeing [32]. When using more than $6 \%$ owf of alum, the color strength has been decreased probably due to increasing the physical damage to the wool fibers. The 3D graphs show the simultaneous effects of factors on the response in which the red area indicates the amounts of the factors resulting in the maximum color value. These graphs are useful for establishing response values and operating conditions that are needed.
Figure 3 shows the mechanism of complex formation between the wool protein, aluminum ion, and dye molecule.

Increasing the dyeing time increased the color value due to the higher amount of dye molecules absorbed by the fibers at prolonged time. Increasing the dyebath $\mathrm{pH}$ from 4 to 8 has decreased the color value of the dyed samples. Wool fiber gains more positive charges at acidic $\mathrm{pH}$ values and the juglone molecules can be better absorbed by positively charged wool fibers at this condition [20, 33]. Increasing the dyeing temperature has increased the color value of the dyed samples due to increasing the exhaustion especially at temperatures higher than $70^{\circ} \mathrm{C}$. This increase in dye-uptake is due to the fibre swelling and breaking the aggregations of dye molecules at higher temperatures which improved the dye diffusion into the wool fiber [20,34].

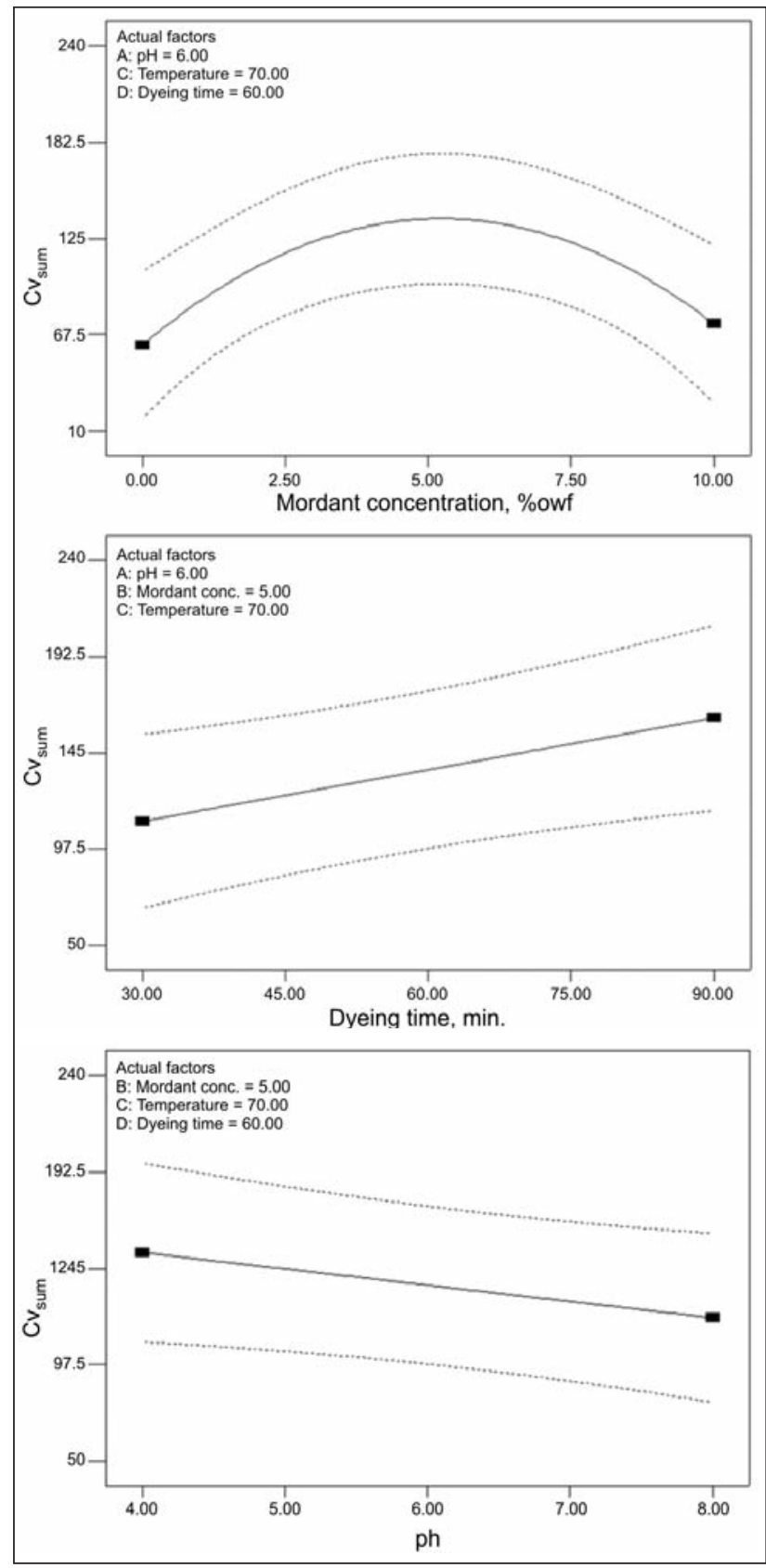

Fig. 2. The individual and simultaneous effects of each factor on color value of dyed samples 


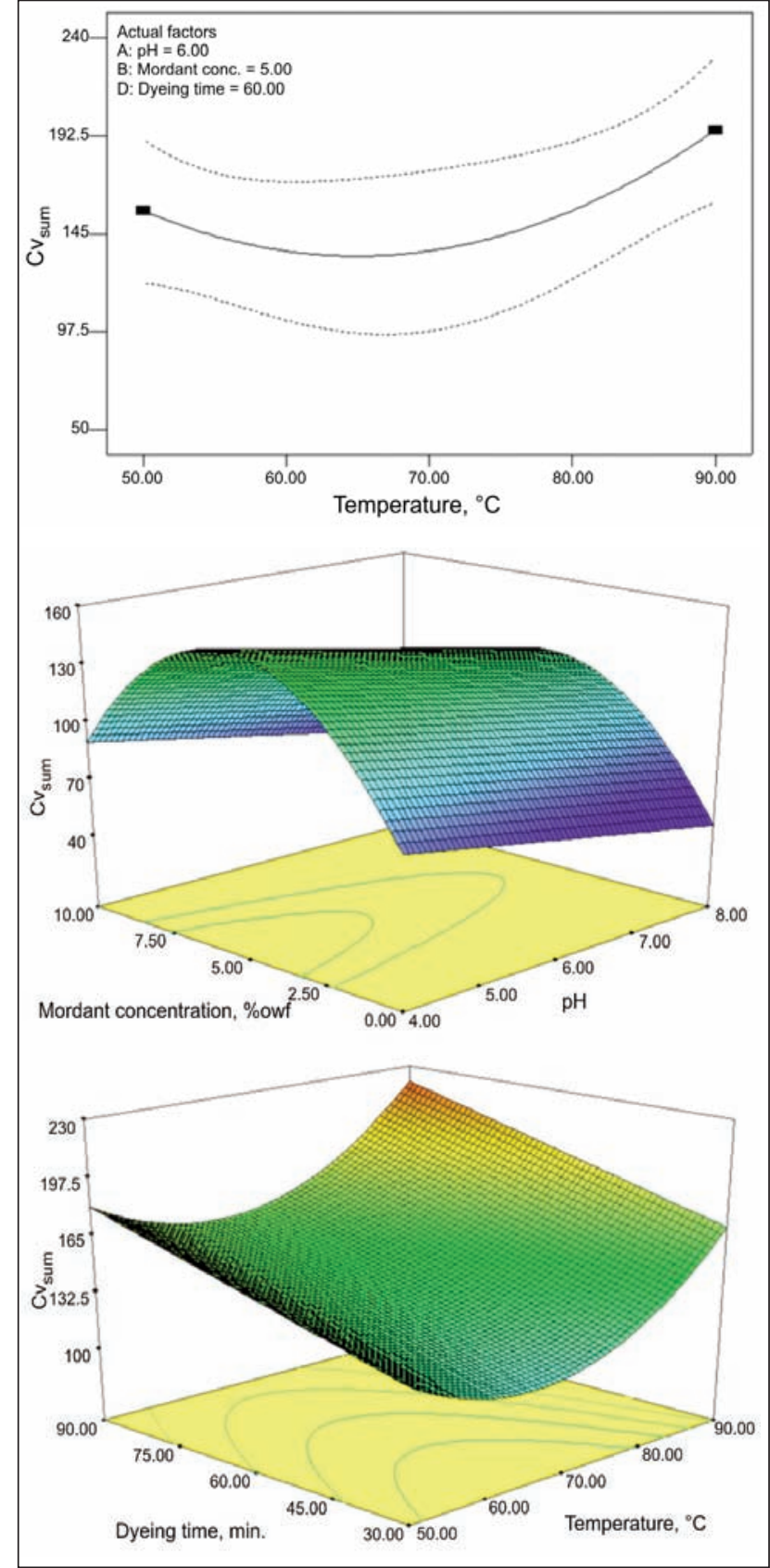

Fig. 2. Continued

\begin{tabular}{|c|c|c|c|c|c|c|}
\hline $\begin{array}{c}\text { Dyeing } \\
\text { pH }\end{array}$ & $\begin{array}{c}\text { Mordant } \\
\text { concen- } \\
\text { tration } \\
\text { (\%owf) }\end{array}$ & $\begin{array}{c}\text { Dyeing } \\
\text { temper- } \\
\text { ature } \\
\left({ }^{\circ} \mathrm{C}\right)\end{array}$ & $\begin{array}{c}\text { Dyeing } \\
\text { time } \\
\text { (min) }\end{array}$ & $\mid \begin{array}{c}\text { Predict- } \\
\text { ed } \\
\mathrm{CV}_{\text {sum }}\end{array}$ & $\begin{array}{l}\text { Experi- } \\
\text { mental } \\
\mathrm{CV}_{\text {sum }}\end{array}$ & $\begin{array}{l}\text { Desir- } \\
\text { ability }\end{array}$ \\
\hline 4 & 6.24 & 90 & 90 & 223.76 & 226.93 & 0.977 \\
\hline
\end{tabular}

\section{Optimization of dyeing process}

The maximum color value was taken as the desired response and the optimal conditions for obtaining the maximum $\mathrm{CV}_{\text {sum }}$ were predicted using the optimization function of Design Expert software. All factors were selected to be "in the range". The optimized conditions are shown in table 5. Good agreement between the predicted $C V_{\text {sum }}$ and the experimental value means that the empirical model derived from RSM can be used to adequately describe the relationship between the factors and response in this study.

\section{CONCLUSION}

In this study, the aqueous extract of Juglansregia bark was used as a natural dye for dyeing of wool. Alum was applied on wool fibers as a mordant using pre-mordanting method. The effects of four independent factors of the dyeing procedure on the color value of the dyed samples were statically studied using response surface methodology. The results showed that the $C V_{\text {sum }}$ had the highest sensitivity to mordant concentration and dyeing temperature compared with other factors. Increasing dyeing time and temperature resulted in increasing the $C V_{\text {sum }}$, but the color value was decreased by increasing the dyebath $\mathrm{pH}$, while there was an optimum amount for mordant concentration (around 6\% owf) to obtain highest effect on color value. The optimal conditions to obtain the highest color value were derived from statistical data. This natural dyecan be considered as a suitable source of natural dye for coloration of wool fibers.

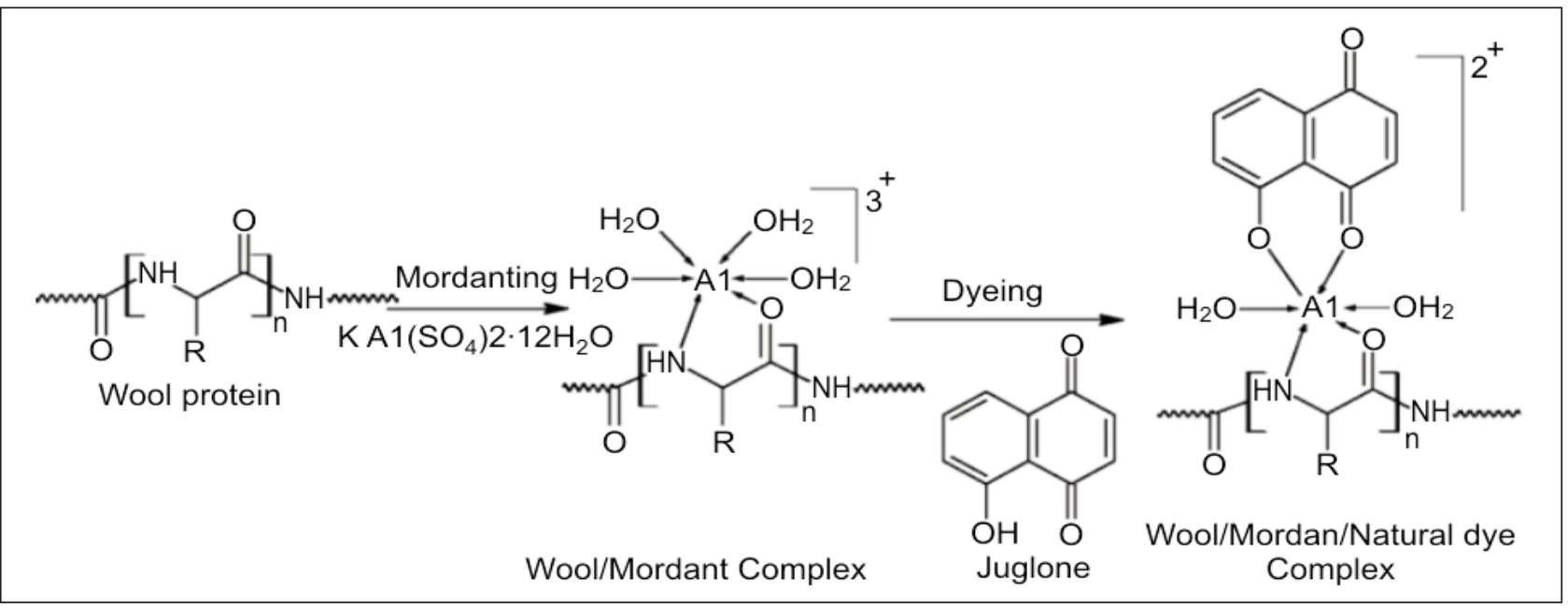

Fig. 3. Mechanism of complex formation between wool, aluminum mordant and juglone dye [32-33] 


\section{BIBLIOGRAPHY}

[1] Hou, X., Fang, F., Guo, X., Wizi, J., Ma, B., Tao, Y., Yang, Y. Potential of sorghum husk extracts as a natural functional dye for wool fabrics. In: ACS Sustainable Chemistry \& Engineering, 2017, vol. 5, issue 6, pp. 4589-4597.

[2] Yusuf, M., Shabbir, M., Mohammad, F. Natural colorants: Historical, processing and sustainable prospects. In: Natural Products and Bioprospecting, 2017, vol. 7, issue 1, pp. 123-145.

[3] Haji, A., Khajeh Mehrizi, M., Akbarpour, R. Optimization of $\beta$-cyclodextrin grafting on wool fibers improved by plasma treatment and assessment of antibacterial activity of berberine finished fabric. In: Journal of Inclusion Phenomena and Macrocyclic Chemistry, 2015, vol. 81, issue 1-2, pp. 121-133.

[4] Haji, A., Qavamnia, S.S. Response surface methodology optimized dyeing of wool with cumin seeds extract improved with plasma treatment. In: Fibers and Polymers, 2015, vol. 16, issue 1, pp. 46-53.

[5] Haji, A., Qavamnia, S.S., Bizhaem, F.K. Optimization of oxygen plasma treatment to improve the dyeing of wool with grape leaves. In: Industria Textila, 2016, vol. 67, issue 4, pp. 244-249.

[6] Baaka, N., Haddar, W., Ben Ticha, M., Amorim, M.T.P., M'Henni, M.F. Sustainability issues of ultrasonic wool dyeing with grape pomace colourant. In: Natural Product Research, 2017, pp. 1-8.

[7] Ben Ticha, M., Haddar, W., Meksi, N., Guesmi, A., Mhenni, M.F. Improving dyeability of modified cotton fabrics by the natural aqueous extract from red cabbage using ultrasonic energy. In: Carbohydrate Polymers, 2016, vol. 154, issue, pp. 287-295.

[8] Haddar, W., Ben Ticha, M., Meksi, N., Guesmi, A. Application of anthocyanins as natural dye extracted from Brassica oleracea L. var. capitata f. rubra: dyeing studies of wool and silk fibres In: Natural Product Research, 2017, pp. 1-9.

[9] Benli, H. An investigation of dyeability of wool fabric with red cabbage (Brassica oleracea L. var.) extract. In: Industria Textila, 2017, vol. 68, issue 2, pp. 108-115.

[10] Hussaan, M., Iqbal, N., Adeel, S., Azeem, M., Tariq Javed, M., Raza, A. Microwave-assisted enhancement of milkweed (Calotropis procera L.) leaves as an eco-friendly source of natural colorants for textile. In: Environmental Science and Pollution Research, 2017, vol. 24, issue 5, pp. 5089-5094.

[11] Barani, H., Rezaee, K. Optimization of dyeing process using Achillea pachycephala as a natural dye for wool fibers. In: Chiang Mai Journal of Science, 2017, vol. 44, issue 4, pp. 1548-1561.

[12] Erdem İşmal, Ö., Yıldırım, L., Özdoğan, E. Valorisation of almond shell waste in ultrasonic biomordanted dyeing: alternatives to metallic mordants. In: The Journal of The Textile Institute, 2015, vol. 106, issue 4, pp. 343-353.

[13] Inan, M., Kaya, D.A., Kirici, S. The effect of dye plant amounts on color and color fastness of wool yarns. In: Industria Textila, 2014, vol. 65, issue 1, pp. 29-32.

[14] Haji, A. Improved natural dyeing of cotton by plasma treatment and chitosan coating; optimization by response surface methodology. In: Cellulose Chemistry and Technology, 2017, vol. 51, issue 9-10, pp. 975-982.

[15] İşmal, Ö.E. Greener natural dyeing pathway using a by-product of olive oil; prina and biomordants. In: Fibers and Polymers, 2017, vol. 18, issue 4, pp. 773-785.

[16] Haddar, W., Baaka, N., Meksi, N., Ticha, M., Guesmi, A., Mhenni, M.F. Use of ultrasonic energy for enhancing the dyeing performances of polyamide fibers with olive vegetable water. In: Fibers and Polymers, 2015, vol. 16, issue 7, pp. 1506-1511.

[17] Haddar, W., Baaka, N., Meksi, N., Elksibi, I., Farouk Mhenni, M. Optimization of an ecofriendly dyeing process using the wastewater of the olive oil industry as natural dyes for acrylic fibres. In: Journal of Cleaner Production, 2014, vol. 66, issue 1, pp. 546-554.

[18] Büyükakinci, B.Y. Investigation of dyeing methods on wool fabrics with hibiscus and its antibacterial efficiency. In: Industria Textila, 2017, vol. 68, issue 2, pp. 103-107.

[19] Haddar, W., Ben Ticha, M., Guesmi, A., Khoffi, F., Durand, B. A novel approach for a natural dyeing process of cotton fabric with Hibiscus mutabilis (Gulzuba): process development and optimization using statistical analysis. In: Journal of Cleaner Production, 2014, vol. 68, issue, pp. 114-120.

[20] Sajed, T., Haji, A., Khajeh Mehrizi, M., Nasiri Boroumand, M., Modification of wool protein fiber with plasma and dendrimer: Effects on dyeing with cochineal. In: International Journal of Biological Macromolecules, 2017, https://doi.org/10.1016/j.ijbiomac.2017.09.038.

[21] Molakarimi, M., Khajeh Mehrizi, M., Haji, A. Effect of plasma treatment and grafting of $\beta$-cyclodextrin on color properties of wool fabric dyed with Shrimp shell extract. In: The Journal of The Textile Institute, 2016, vol. 107, issue 10, pp. 1314-1321.

[22] Vankar, P. S., Shukla, D., Wijayapala, S. Innovative Silk dyeing using Enzyme and Rubia cordifolia extract at room temperature. In: Pigment \& Resin Technology, 2017, vol. 46, issue 4, p. null.

[23] Zahid, M., Bhatti, I.A., Adeel, S., Saba, S. Modification of cotton fabric for textile dyeing: industrial mercerization versus gamma irradiation. In: The Journal of The Textile Institute, 2017, vol. 108, issue 2, pp. 287-292.

[24] Stanculescu, I., Chirila, L., Popescu, A., Cutrubinis, M. Gamma pre-irradiation effects on natural dyeing performances of proteinic blended yarns. In: Environmental Engineering and Management Journal, 2017, vol. 16, issue 4, pp. 913-920. 
[25] Nasirizadeh, N., Dehghanizadeh, H., Yazdanshenas, M.E., Moghadam, M.R., Karimi, A. Optimization of wool dyeing with rutin as natural dye by central composite design method. In: Industrial Crops and Products, 2012, vol. 40, issue Supplement C, pp. 361-366.

[26] Rahbar, R.S., Haji, A. Use of D-optimal design to model and the analysis of the effect of the draw ratio on some physical properties of hot multistage drawn nylon 6 fibers. In: Journal of Applied Polymer Science, 2013, vol. 130, issue 2, pp. 1337-1344.

[27] Whitcomb, P.J., Anderson, M.J., RSM simplified: optimizing processes using response surface methods for design of experiments, CRC press. Boca Raton, USA, 2004.

[28] Triefenbach, F. Design of experiments: the D-optimal approach and its implementation as a computer algorithm, Department of Computing Science, Umea University, Umea, Sweden, 2008.

[29] Barani, H., Broumand, M.N., Haji, A., Kazemipur, M. Optimization of dyeing wool fibers procedure with isatis tinctoria by response surface methodology. In: Journal of Natural Fibers, 2012, vol. 9, issue 2, pp. 73-86.

[30] Zakavi, F., Golpasand Hagh, L., Daraeighadikolaei, A., Farajzadeh Sheikh, A., Daraeighadikolaei, A., Leilavi Shooshtari, Z. Antibacterial effect of juglans regia bark against oral pathologic bacteria. In: International Journal of Dentistry, 2013, vol. 2013, issue, pp. 1-5.

[31] Chaieb, K., Kouidhi, B., Slama, R.B.E.N., Fdhila, K., Zmantar, T., Bakhrouf, A. Cytotoxicity, Antibacterial, antioxidant, and antibiofilm properties of Tunisian juglans regia bark extract. In: Journal of Herbs, Spices \& Medicinal Plants, 2013, vol. 19, issue 2, pp. 168-179.

[32] Bukhari, M.N., Shahid-ul-Islam, Shabbir, M., Rather, L.J., Shahid, M., Singh, U., Khan, M.A., Mohammad, F. Dyeing studies and fastness properties of brown naphtoquinone colorant extracted from Juglans regia $L$ on natural protein fiber using different metal salt mordants. In: Textiles and Clothing Sustainability, 2017, vol. 3, issue 1, pp. 1-9.

[33] Ali Khan, M., Shahid UI, I., Mohammad, F. Extraction of natural dye from walnut bark and its dyeing properties on wool yarn. In: Journal of Natural Fibers, 2016, vol. 13, issue 4, pp. 458-469.

[34] Kamel, M.M., El-Shishtawy, R.M., Yussef, B.M., Mashaly, H. Ultrasonic assisted dyeing: III. Dyeing of wool with lac as a natural dye. In: Dyes and Pigments, 2005, vol. 65, issue 2, pp. 103-110.

$$
\begin{gathered}
\text { Authors: } \\
\text { AMINODDIN HAJI }{ }^{1} \\
\text { SAYYED SADRODDIN QAVAMNIA }{ }^{1} \\
\text { MAJID NASIRIBOROUMAND }{ }^{2} \\
\text { rtment of Textile Engineering, Birjand B } \\
\text { Islamic Azad University, Birjand, Iran } \\
\text { Kert, Faculty of Art, Shahid Bahonar Un, Iran } \\
\text { Kerman } \\
\text { Corresponding author: } \\
\text { AMINODDIN HAJI } \\
\text { e-mail: ahaji@iaubir.ac.ir }
\end{gathered}
$$

\section{Corresponding author:}

${ }^{1}$ Department of Textile Engineering, Birjand Branch

${ }^{2}$ Department of Carpet, Faculty of Art, Shahid Bahonar University of Kerman

e-mail: ahaji@iaubir.ac.ir, qavamnia@gmail.com, nasiri@mail.uk.ac.ir 